\title{
Epidermal Morphology of the Pinnae of Angiopteris, Danaea, and Marattia
}

\author{
Cristina Rolleri, Amélia Deferrari, and María del Carmen lavalle \\ Laboratory of Botany, Museo de La Plata, Paseo del Bosque, 1900 La Plata, Argentina
}

This is a study of adult epidermis morphology in 17 species of Angiopteris Hoffm., Danaea J. E. Smith, and Marattia Swartz. Epidermal patterns, adult stomata, indument, and idioblasts were studied. Hill and Camus (1986) made an overview of characters of some extant species of Marattiales as part of a cladistic study of extant and fossil members of the order. The epidermal characters they used were subsidiary cells of the stomata, dimensions of the stomata, walls of epidermal cells, and idioblasts. The only character of indument they included in their study was the presence or absence of scales. Rolleri et al. (1987) made the first detailed study dealing with pinna and pinnule indument in the Marattiaceae, although Holttum (1978) had made some general comments on petiole and rhizome scales of Angiopteris, illustrating two species. He suggested that Angiopteris pinna trichomes were diagnostic but needed detailed study. Rolleri et al. (1987) strongly pointed out that epidermal characters are diagnostic at the species level in the Marattiaceae and speculated on generic affinities within the Marattiales.

\section{Materials AND MEthods}

Adult epidermis was described according to the terminology of Rolleri and Deferrari (1986) and Rolleri et al. (1987). Adult stomata were described following the criteria of Stace (1965), van Cotthem $(1970,1971)$, and Wilkinson (1979). Lellinger's (1985) concept of trichomes was adopted, as well as the terminology of Theobald et al. (1979) for each trichome type and model for its description.

Adult pinnae were cleared with $3 \% \mathrm{NaOH}$. General epidermal stains were Foster's (1934) and safranin-aniline blue (Gurr, 1965). Specific stains and tests were Bismark brown and an iodized $\mathrm{ZnCl}_{2}$ test for wall cellulose, phloroglucinol for lignin, $\mathrm{FeSO}_{4}$ for tannins, phenol for amorphous silica in epidermal idioblasts, and Sudan IV-etilenglicol (Gurr, 1965) and Frohne's (1965) test using a saturated solution of erythrosin in isopropanol for cutin. All material was examined and illustrated using a Wild M-20 microscope.

Specimens as available were examined from the Instituto Miguel Lillo, Tucumán (LIL), the Museo de La Plata (LP), and the Instituto Darwinion, San Isidro (SI). Some 50-100 slides were made of each species and have been deposited at LP.

Angiopteris angustifolia K. Presl-PHILIPPINES: Luzon: Lagunas, Mt. Maquiling, Merrill 631a and 631b (both SI). A. cartilagidens Christ-PHILIPPINES: Luzon: Benguet, Merrill 928 (SI). A. evecta (Forst.) Hoffm.-INDIA: Assam, Nambor Forest, Mann 1046 (SI); Mont Khassia [Khassi Hills], J. D. Hooker \& T. T. [probably T. Thompson] s. n. (SI 27950); JAPAN: Insula Bonin, sin coll. 121 (SI); NEW GUINEA: Papua New Guinea, La Helberg, Hahn s. n. (SI 27949); NEW CALEDONIA: 
Chart 1. Stomata characteristics.

\begin{tabular}{|c|c|c|c|c|c|c|}
\hline Characters & Stomata Size & Stomata & ensity & Number of & Number of & \\
\hline Species & A & B & $\mathrm{C}$ & $\begin{array}{l}\text { Subsidiary } \\
\text { Cells }\end{array}$ & $\begin{array}{l}\text { Peristomatic } \\
\text { Cells }\end{array}$ & $\begin{array}{l}\text { Adult types of } \\
\text { Stomata }\end{array}$ \\
\hline A. angustifolia & $46 \times 28$ & (30) $\underline{33}(35)$ & $120-140$ & $1-2$ & $5-10$ & $\begin{array}{l}\text { Irregular Cyclocytic } \\
\text { Contiguous }\end{array}$ \\
\hline A. cartilagidens & $54 \times 32$ & (32) $\underline{34}(36)$ & $128-144$ & 1 (Raro 2) & $4-5(7)$ & $\begin{array}{l}\text { Typical Cyclocytic } \\
\text { Tetracytic } \\
\text { Staurocytic/ } \\
\text { Contiguous }\end{array}$ \\
\hline A. evecta & $84 \times 32$ & (20) $\underline{25}(28)$ & $80-122$ & 1 & $3-4(5)$ & $\begin{array}{l}\text { Irregular Cyclocytic } \\
\text { Tetracytic } \\
\text { Staurocytic } \\
\text { Anisocytic }\end{array}$ \\
\hline A. pruinosa & $48 \times 28$ & (21) $\underline{27}$ (33) & $80-130$ & $1-2$ & $4-10$ & $\begin{array}{l}\text { Irregular Cyclocytic } \\
\text { Contiguous }\end{array}$ \\
\hline D. alata & $74 \times 32$ & (4) $\underline{6}$ (9) & $20-30$ & $1-2$ & $4-6(8)$ & $\begin{array}{l}\text { Irregular Cyclocytic } \\
\text { Tetracytic } \\
\text { Hexacytic }\end{array}$ \\
\hline D. elliptica & $82 \times 34$ & (8) $12(16)$ & $30-60$ & $1-2$ & $3-8$ & Hexacytic \\
\hline D. excurrens & $62 \times 34$ & (4) $\underline{5}(8)$ & $20-40$ & $1-2$ & $4-5$ (9) & $\begin{array}{l}\text { Typical Cyclocytic } \\
\text { Irregular Cyclocytic } \\
\text { Tetracytic } \\
\text { Contiguous }\end{array}$ \\
\hline D. grandifolia & $62 \times 32$ & (11) $\underline{14}$ (17) & $40-60$ & 1 & $4-5$ & $\begin{array}{l}\text { Irregular Cyclocytic } \\
\text { Tetracytic } \\
\text { Contiguous }\end{array}$ \\
\hline M. attenuata & $78 \times 56$ & (25) $\underline{27}(29)$ & $100-120$ & 1 & $4-5$ & $\begin{array}{l}\text { Typical Cyclocytic } \\
\text { Tetracytic } \\
\text { Staurocytic } \\
\text { Contiguous }\end{array}$ \\
\hline M. douglassii & $50 \times 30$ & (20) $\underline{23}(25)$ & $80-100$ & 1 & $4-6$ & $\begin{array}{l}\text { Typical Cyclocytic } \\
\text { Tetracytic } \\
\text { Hexacytic } \\
\text { Contiguous }\end{array}$ \\
\hline M. excavata & $58 \times 28$ & (10) $\underline{12}(16)$ & $40-60$ & 1 & 4 & $\begin{array}{l}\text { Typical Cyclocytic } \\
\text { Tetracytic }\end{array}$ \\
\hline M. fraxinea & $48 \times 28$ & (16) $\underline{19}(22)$ & $60-80$ & $1-2$ & $4-6$ & Tetracytic \\
\hline M. pellucida & $48 \times 28$ & (10) $\underline{12}(16)$ & $40-60$ & 1 & $4-5$ & $\begin{array}{l}\text { Tetracytic } \\
\text { Anomocytic }\end{array}$ \\
\hline M. raddi & $64 \times 40$ & (2) $\underline{3}(6)$ & $10-20$ & 1 & 4 & $\begin{array}{l}\text { Tetracytic } \\
\text { Anomocytic }\end{array}$ \\
\hline M. silvatica & $84 \times 44$ & (8) $\underline{10}(12)$ & $30-50$ & 1 & $4-6$ & $\begin{array}{l}\text { Irregular Cyclocytic } \\
\text { Tetracytic } \\
\text { Contiguous }\end{array}$ \\
\hline M. werneri & $48 \times 22$ & (11) $\underline{14}$ (18) & $40-60$ & 1 & $3-5$ & $\begin{array}{l}\text { Typical Cyclocytic } \\
\text { Anisocytic } \\
\text { Contiguous }\end{array}$ \\
\hline
\end{tabular}

A. Length and width in $\mu \mathrm{m}$; mean values given.

B. Number per $0.25 \mathrm{~mm}^{2}$; usual and extreme values given.

C. Number per $1 \mathrm{~mm}^{2}$, range of variation given. 
Bords de la rivière Yaboué, A. R. [leg. Franc] s. n. (SI). A. lygodiifolia Rosenst.-JAPAN: Honshu: Mie, Owaso-shi, Kata-ku Peninsula, Ohba 651147 (SI); Kyuku: Isl. Tokuno-Shima, Kagoshima Prefecture, en route to Mt. Amagidake, Tokunoshima-cho, Ooshima-gun, Iwatsuki et al. 646 and 173 (both LP). A. pruinosa Kunze-JAVA: Tengger Montes, Wonosari, Mousset 59 (SI).

Danaea alata J. E. Smith-WEST INDIES: Dominica: St. David Parish, Central Forest Reserve, Dleau Gommier, Lellinger 472 (LP); BRAZIL: Paraná: Serra do Mar, Ypiranga, Dusén 12123 (SI): PARAGUAY: Cordillera de Cerro León a l'est de Rivayn, Balansa 2817 (SI). D. elliptica J. E. SmithGUATEMALA: Alta Verapaz: near Cubilquitz, von Tuerkheim II 491 (SI); PUERTO RICO: Río Piedras near S. Juan, Hioram s. n. (LIL 20585). WEST INDIES: St. Vincent: Cumberland Mountain, Morton 5897 (LP); BRAZIL: Pará: Rio Cururú, Alto Tapajós, Anderson 10593 (LP). D. excurrens Rosenst.-BRAZIL: Sta. Catarina: Flapocasinho, Hansch 224 (SI). D. grandifolia (L.) Underw.COSTA RICA: Heredia: ca. $4 \mathrm{~km}$ upstream from Puerto Viejo at Finca La Selva, Mickel 3490 (LP); Puntarenas: vic. of the biological field station at Finca Wilson near S. Vito de java, Mickel 3049 (LP).

Marattia attenuata Labill.-NEW CALEDONIA: Mt. Koghis, Bonati 653 (SI); Yaboué, Franc s. n. (LIL 20583). M. douglassii (K. Presl) Baker-HAWAII: Oahu: Haiawa Valley, Degener \& Wiebke 3153 (SI). M. excavata Underw.-COSTA RICA: Puntarenas: $1-4 \mathrm{~km} \mathrm{~S}$ of the biological field station at Finca Wilson near S. Vito de Java, Mickel 3119 (LP). M. fraxinea J. E. Smith-GABON: Forêt du Mayambé bayaka Gorges de la Dougonatzi [?], affluent de la Rianga, Djengila, Testu s. n. (LIL 293622); TANZANIA: Mt. Kilimanjaro, Schlieben 4711 (LIL 446970). AUSTRALIA: New South Wales: Sydney, Norfolk Island, Robinson s. n. (SI 27956). M. pellucida K. Presl-PHILIPPINES: Mindanao: Camiguin de Mindanao, Ramos 1169 (SI). M. raddii Desv.-BRAZIL: Sta. Catarina: Morro de trombo, Schmalz 222 (SI); Sertão de Sagoa, Isla Sta. Catarina, Rohn 1036 (SI); Rio Grande do Sul: Sta. Cruz, Juergens 223 (SI). M. silvatica Blume-PHILIPPINES: Luzon: Benguet, Merrill 929 (SI). M. werneri Rosenst.-NEW GUINEA: Papua New Guinea: Mt. Gelu, Werner 49 (SI).

\section{EPIDERMAL PATTERNS}

Adult epidermis shows polygonal, subpolygonal, and sinuate patterns, as described for Lycopodium by Rolleri \& Deferrari (1986). Variations in the latter are related to sinus distance and width; distantly sinuate, angularly sinuate, frequently sinuate, and subfrequently sinuate patterns are seen. Epidermal patterns may be identical or different in the hypophyll and epiphyll. The same is true for cell length:width ratios and the general contour in surface view. In many instances, the hypophyll greatly differs from the epiphyll in possessing stomata, idioblasts, and trichomes.

Polygonal epidermal patterns are found both in the hypophyll and the epiphyll of M. attenuata (Figs. 3A-C). Subpolygonal patterns also appear in both pinna faces of $A$. pruinosa (Figs. 1A-B) and in the epiphyll of $A$. angustifolia (Fig. 1C). Subpolygonal to sinuate patterns have been observed in the epiphylls of M. douglassii (Fig. 3D) and M. fraxinea (Fig. 3J), whereas the hypophylls of the latter three species are intermediate between distantly and frequently sinuate (Figs. $1 \mathrm{E}, 3 \mathrm{E}-\mathrm{F}, 3 \mathrm{~K}$ ).

Distantly sinuate patterns appear in the hypophyll and epiphyll of $A$. cartilagidens (Figs. 1F-G) and M. excavata (Figs. 3G-I) and also in the epiphyll of $M$. pellucida and $M$. raddii (Figs. 4A, E). In the hypophyll, the latter two species have a somewhat irregular, frequently sinuate pattern with frequent although diversely ample undulations (Figs. $4 \mathrm{~B}-\mathrm{D}$ and $4 \mathrm{~F}-\mathrm{G}$ ). A variation of this epidermal pattern appears on both faces of $M$. silvatica pinnae (Figs. $4 \mathrm{H}-\mathrm{I}$ ), showing a distinctly sinuous but irregular outline-at times curved, at times angular-in the epiphyll and the hypophyll, the latter seemingly more irregular. 

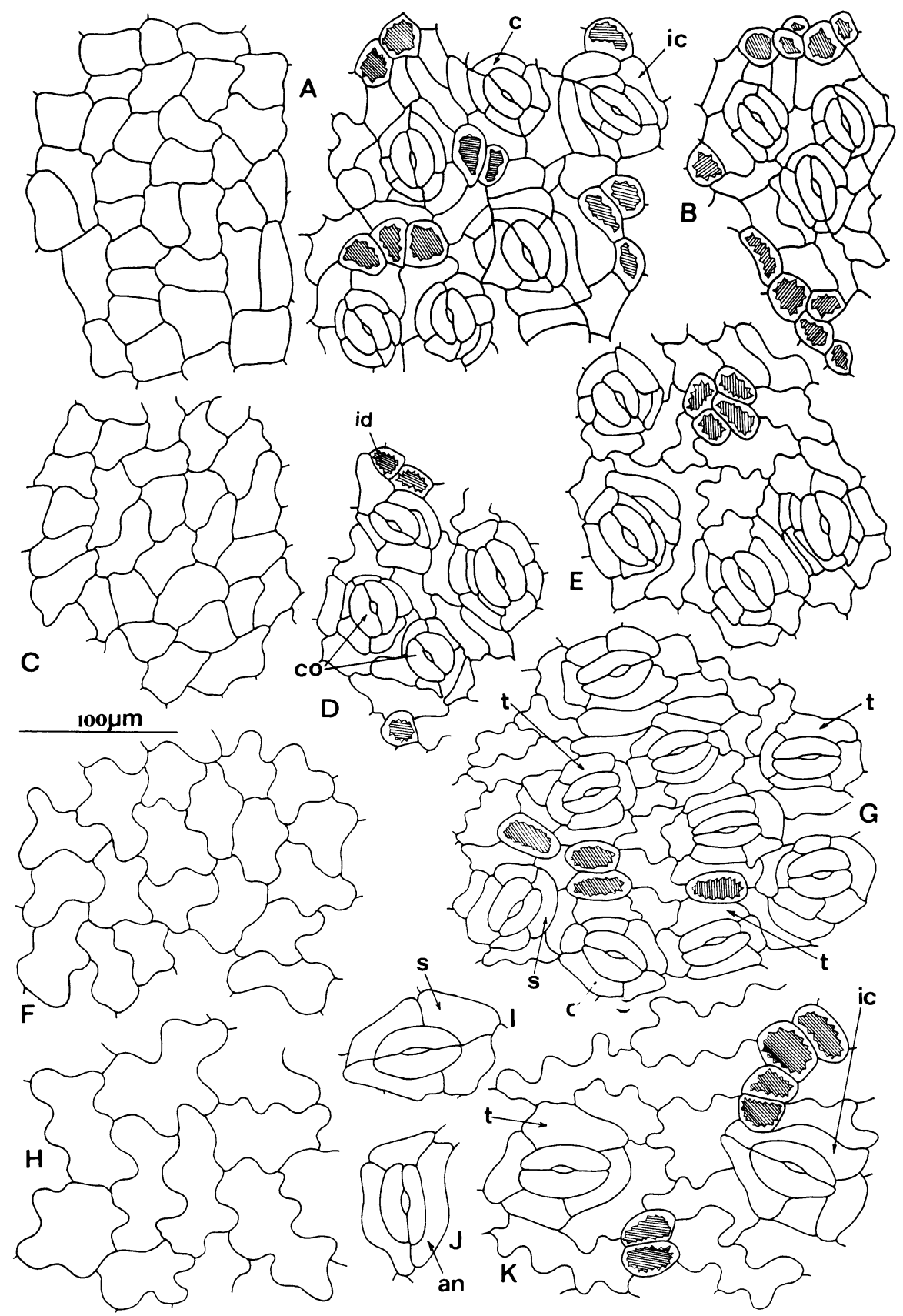

Fig. 1. Epidermis in Angiopteris. A. A. pruinosa epiphyll. B. A. pruinosa hypophyll. C. A. angustifolia epiphyll. D-E. A. angustifolia hypophyll. F. A. cartilagidens epiphyll. G. A. cartilagidens hypophyll. H. A. evecta epiphyll. I-K. A. evecta hypophyll. The stomata types are: an $=$ anisocytic, $\mathrm{c}=$ cyclocytic, $\mathrm{co}=$ contiguous, ic $=$ irregular cyclocytic, $\mathrm{s}=$ staurocytic, and $\mathrm{t}=$ tetracytic. The other abbreviation is: $\mathrm{id}=$ idioblast. 
Frequently sinuate patterns are found in both faces of $M$. werneri (Figs. 4J-N) and generally in Danaea. Most typical is D. grandifolia (Figs. 2P-R), with $D$. nodosa (L.) J. E. Smith very similar (Rolleri et al., 1987). In D. alata (Figs. 2A-E), D. excurrens (Figs. 2J-O), and D. elliptica (Figs. 2F-I), the epiphyll is frequently sinuate, but the pattern is somewhat modified by important irregularities in wall thickness: the contours are more uniformly frequently sinuate, with the exception of $D$. elliptica (Figs. $2 \mathrm{~F}-\mathrm{I}$ ), where the epidermal pattern is angularly to subangularly sinuate.

Cell length:width (l:w) ratio also varies. In general, it can be said that for the Marattiaceae the longer (more anisodiametric) a cell is, the larger it is compared to the isodiametric ones. Epidermal cells tend to be isodiametric $(\mathrm{l}: \mathrm{w}=1: 1)$ in the epiphyll of $A$. angustifolia (Fig. 1C) and a. pruinosa (Fig. 1A) and in both the epiphyll and hypophyll of $D$. grandifolia (Figs. 2P-R) and $M$. attenuata (Figs. 3A-C). (In M. attenuata the epidermis looks like a very regular mosaic, especially in the hypophyll). Ratios of 2:3-3:1 are found in the epiphyll of $D$. alata (Fig. 2A), the hypophyll of A. angustifolia (Figs.1D-E), A. cartilagidens (Fig. 1G), and A. pruinosa (Fig. 1B), and in the epiphyll and hypophyll of $D$. elliptica (Figs. 2F-I), D. excurrens (Figs. 2J-O), M. douglassii (Figs. 3D-F), M. excavata (Figs. 3G-I), M. fraxinea (Figs. 3J-K), M. pellucida (Figs. 4A-D), M. raddii (Figs. 4E-G), and M. silvatica (Figs. $4 \mathrm{H}-\mathrm{I}$ ). Epidermal cells with a ratio of ca. 4:1-5:1 are found in M. werneri (Figs. 4J-N), and up to 6:1-7:1 in A. evecta (Fig. $1 \mathrm{H}-\mathrm{I}$ ).

Cell wall thickness also varies. Epidermal cell walls are relatively thin in the Angioptris and Marattia species we observed, except for A. pruinosa and $M$. attenuata. Walls of the polygonal epidermal cells of the latter are up to 3.5-4 $\mu \mathrm{m}$ thick (Figs. 3A-C). Danaea species, as already mentioned, have frequently sinuate patterns and the cell walls are irregularly thickened. Although these thickenings cannot be compared to those of $M$. attenuata, values of $2-3 \mu \mathrm{m}$ occur (Figs. 2B, G, I, K, Q). Cells with maximum thickenings always occur in the epiphyll.

Cuticular ornamentation (folds, granules, striae, and different kinds of undulations of the external cuticular surface), domes, papillae, and epicuticular waxes were recently observed by us in an SEM study.

\section{Adult Stomata}

Six stomata types are found among the species we studied, as described below. Working with adult specimens has proven beyond any doubt that ontogenetic approaches are out of the question, due to the impossibility of determining the developmental stages leading to an adult stoma.

Anisocytic stomata (an), with guard cells surrounded by three cells, one of which is generally smaller than the other two, are rather rare in Danaea, but were observed in A. evecta (Fig. 1J) and M. werneri (Fig. 4L).

Anomocytic stomata (a), with subsidiary cells not distinguishable from the other epidermal cells, are infrequent but more common than the anisocytic type. 

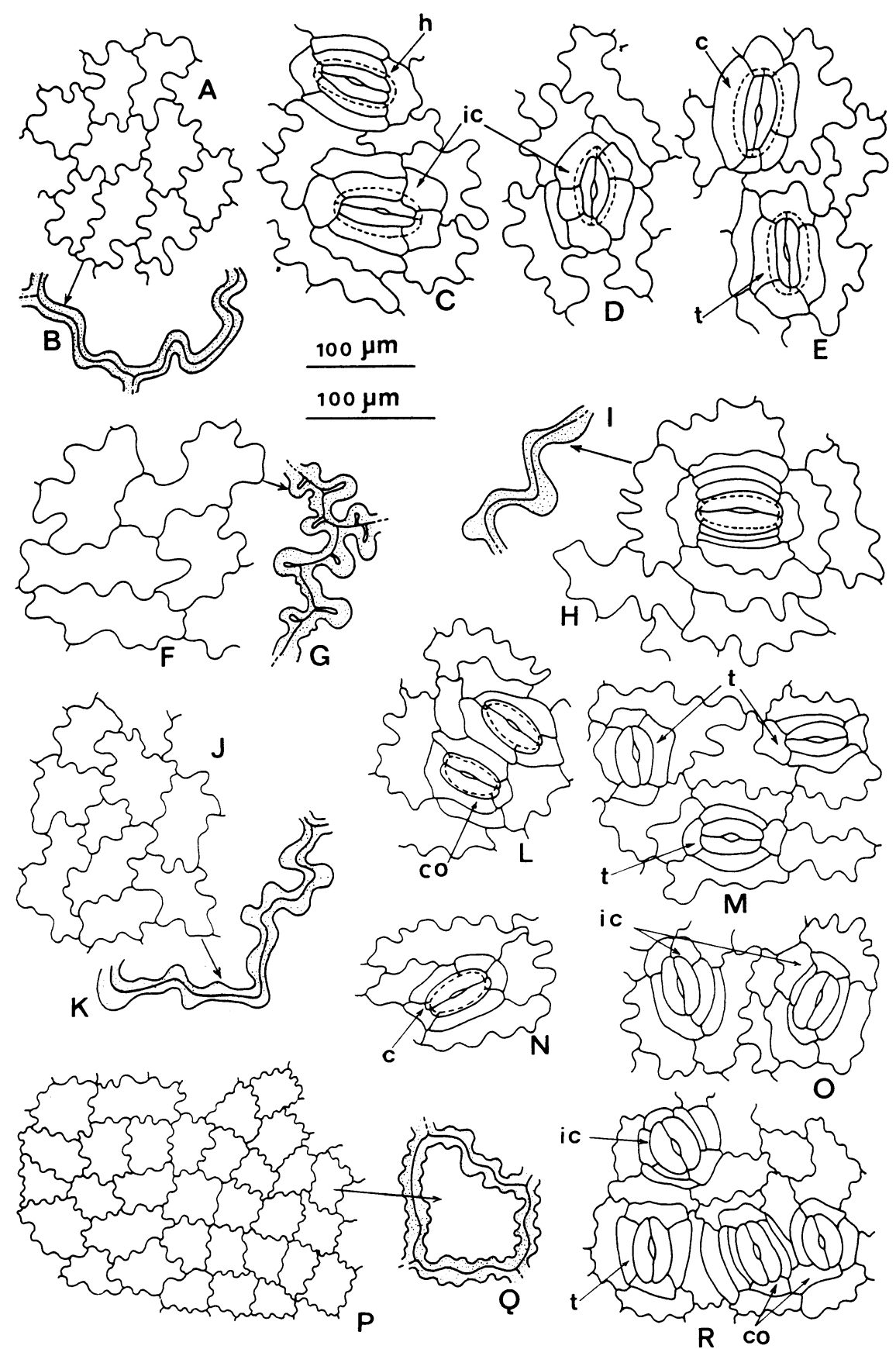

FIG. 2. Epidermis in Danaea. A-B. D. alata epiphyll. C-E. D. alata hypophyll. F-G. D. elliptica epiphyll. H-I. D. elliptica hypophyll. J-K. D. excurrens epiphyll. L-O. D. excurrens hypophyll. P-Q. D. grandifolia epiphyll. R. P. grandifolia hypophyll. The stomata types are: $\mathrm{c}=$ cyclocytic, co $=$ contiguous, $\mathrm{h}=$ hexacytic, ic $=$ irregular cyclocytic, $\mathrm{s}=$ staurocytic, and $\mathrm{t}=$ tetracytic. 
Not seen in Danaea, they were observed in M. pellucida (Fig. 4B) and M. raddii (Fig. 4G)

Cyclocytic stomata (c) are most common in the Marattiaceae. Using Stace's (1965) precise definition modified by van Cotthem (1970), this type includes stomata in which the guard cells are surrounded by a varying, narrow, simple ring of subsidiary cells. An outer ring containing a variable number of subsidiary cells may enclose the inner ring of four or more (generally five) cells. Mature cyclocytic stomata were named the "Angiopteris-type" (Maroti, 1960), "encyclocytic" (Stromberg, 1956), and "amphicyclic" (Pant, 1965). The "Angiopteris-type" has been found in three genera of the Marattiales (Rolleri et al. 1987), and so employing this name is not advisable; Stromberg's term is a synonym of Stace's; and Pant's name assumed perigenous development.

We found that cyclocytic stomata occur in two subtypes, typical and irregular. Typical cyclocytic stomata, with guard cells surrounded by a 5- or 6-celled ring, have been found in A. cartilagidens (Fig. 1G), D. excurrens (Fig. 2N), M. attenuata (Fig. 3C), M. douglassii (Figs. 3E-F), M. excavata (Figs. 3H-I), and $M$. werneri (Fig. 4L).

Irregular cyclocytic stomata (ic) have more than five or six and often up to 10 subsidiary cells set in two rings, with the outer ring irregular, incomplete, or shared with another stoma. The latter were called "contiguous stomata" by Rolleri et al. (1987) and have been observed in A. evecta (Fig. 1K), D. alata (Figs. 2C-D), and M. silvatica (Fig. 4I). Extreme cases of irregularity, with 1 or 2 rings of subsidiary cells, can be seen in A. pruinosa (Fig. 1B), A. angustifolia (Figs. 1D-E), D. excurrens (Figs. 2L, O), and D. grandifolia (Fig. 2R).

From a descriptive point of view, and in agreement with the more adequate definitions of stomata types (Metcalfe, 1961; Stace, 1965; van Cotthem, 1971; Wilkinson, 1979), both the tetracytic and staurocytic types are considered to be variants of the cyclocytic types.

Tetracytic stomata ( $t$ ), with guard cells surrounded by four subsidiary cells, two lateral and parallel to the guard cells and two polar and usually smaller, appear very often in all species of the three genera, including $A$. cartilagidens (Fig. 1G), A. evecta (Fig. 1K), D. alata (Fig. 2E), D. excurrens (Fig. 2M, D. grandifolia (Fig. 2R), M. attenuata (Fig. 3C), M. douglassii (Fig. 3E), M. excavata (Fig. 3H), F. fraxinea (Fig. 3K), M. pellucida (Fig. 4C), M. raddii (Fig. 4F), and M. silvatica (Fig. 4I).

Hexacytic stomata $(\mathrm{h})$ are a variant of the tetracytic type and appear in Danaea and Marattia. According to van Cotthem (1971), they include an additional pair of lateral subsidiary cells. The examples we observed show polar subsidiary cells of regular size with crescent-shaped and somewhat encircling lateral subsidiary cells, as in D. alata (Fig. 2C), D. elliptica (Fig. 2H), and M. douglassii (Fig. 3F).

Occasionally, more than one pair of polar subsidiary cells and up to two or three pairs of lateral subsidiaries have been observed in stomata which could provisionally be considered also as irregular cyclocytic. They have 8-12 subsidiary cells distributed in two rings, the inner one regular and the outer one irregular and sometimes becoming part of contiguous stomata. The distribution 

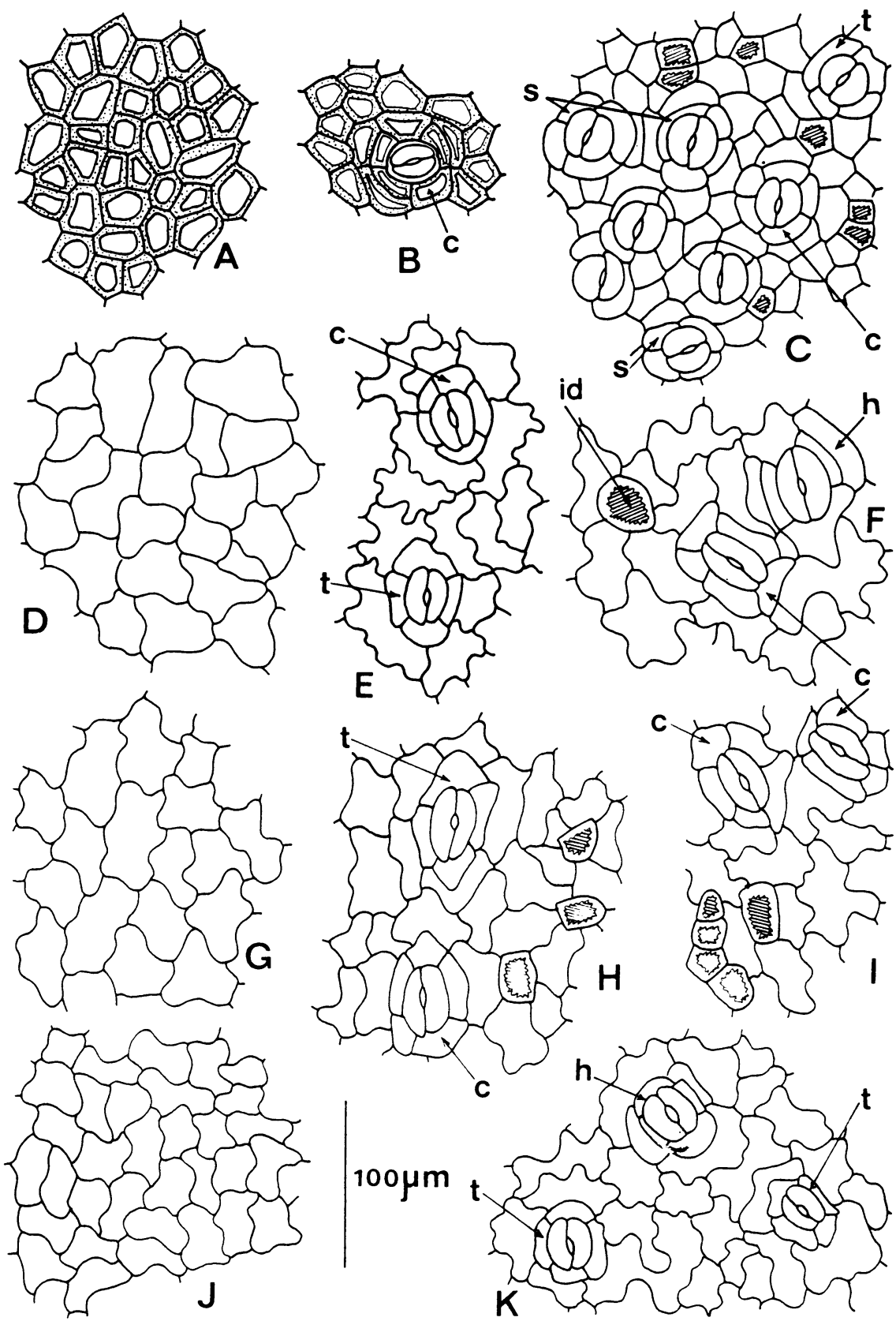

Fig. 3. Epidermis in Marattia. A. M. attenuata epiphyll. B-C. M. attenuata hypophyll. D. M. douglassii epiphyll. E-F. M. douglassii hypophyll. G. M. excavata epiphyll. H-I. M. excavata hypophyll. J. M. fraxinea epiphyll. K. M. fraxinea hypophyll. The stomata types are: $\mathrm{c}=$ cyclocytic, $\mathrm{h}=$ hexacytic, $\mathrm{s}=$ staurocytic, and $\mathrm{t}=$ tetracytic. The other abbreviation is: $\mathrm{id}=$ idioblast. 
of subsidiary cells suggests that the subsidiary cells of a basic tetracytic stoma have undergone extra divisions.

We have dealt with contiguous stomata (co) elsewhere (Rolleri et al., 1987). These share subsidiary cells of either of their rings, more commonly the outer one. These are very frequent in Angiopteris, perhaps due to the high density of stomata in this genus. However, they were also observed in Danaea and Marattia. Continguous stomata were found in A. angustifolia (Figs. 1D-E), A. cartilagidens (Fig. 1G), A. pruinosa (Fig. 1B), D. excurrens (Fig. 2L), D. grandifolia (Fig. 2R), M. attenuata (Fig. 3C), M. douglassii (Fig. 3F), M. silvatica (Fig. 4I), and M. werneri (Fig. 4L).

Staurocytic stomata (s) have four or sometimes five similar subsidiary cells with anticlinal walls arranged crosswise to the guard cells (Wilkinson, 1979). These were found in A. cartilagidens (Fig. 1G), A. evecta (Fig. 1I), and M. attenuata (Fig. 3C).

From the foregoing, it is evident that all of the species under analysis exhibit two, three, and even up to seven types of stomata with comparable frequency. Because of this, stomata types are not by themselves a valid diagnostic character at the species level.

The relationship of guard cells to the epidermal surface may be diagnostic at the generic level in the Marattiaceae. In Angiopteris the guard cells protrude above the epidermis surrounding them, in Marattia they are at the same level as the epidermis, and in Danaea they are as in Marattia or are slightly sunken. In the first instance, the guard cells conform to the term "aquatic" stomata, in the latter two, to "terrestrial" stomata (Haberlandt, 1965). The difference between aquatic and terrestrial stomata is structural and presumably has an ecological basis. In aquatic stomata, the guard cells are elevated above the lamina surface and their opposing walls are at angles to one another and touch only at the outermost point, forming an ample cavity toward the interior. In terrestrial stomata, the guard cells are not elevated above the lamina surface and their opposing walls are parallel to one another and touch nearly throughout, and so only a small cavity is formed toward the interior. Aquatic stomata are found in plants growing in areas where the atmospheric humidity can reach $100 \%$ and where it is possible for water vapor to condense on the fronds, occluding the stomatal pores unless they protrude above the lamina surface, as they do in aquatic stomata.

The outstanding characters of the stomata we studied are summarized in Chart 1 . The number of peristomatic cells includes both subsidiary and/or neighboring cells. Two standards were used for stomata density, a $0.25 \mathrm{~mm}^{2}$ field and a $1 \mathrm{~mm}^{2}$ field. The former is customary in our research, whereas the latter was used by certain other authors for several species of the family (Probst, 1971).

\section{INDUMENT}

Trichomes are found only on the pinnae hypophyll, never the epiphyll of the genera we studied. No uni- or bicellular trichomes are known. Trichomes are of 

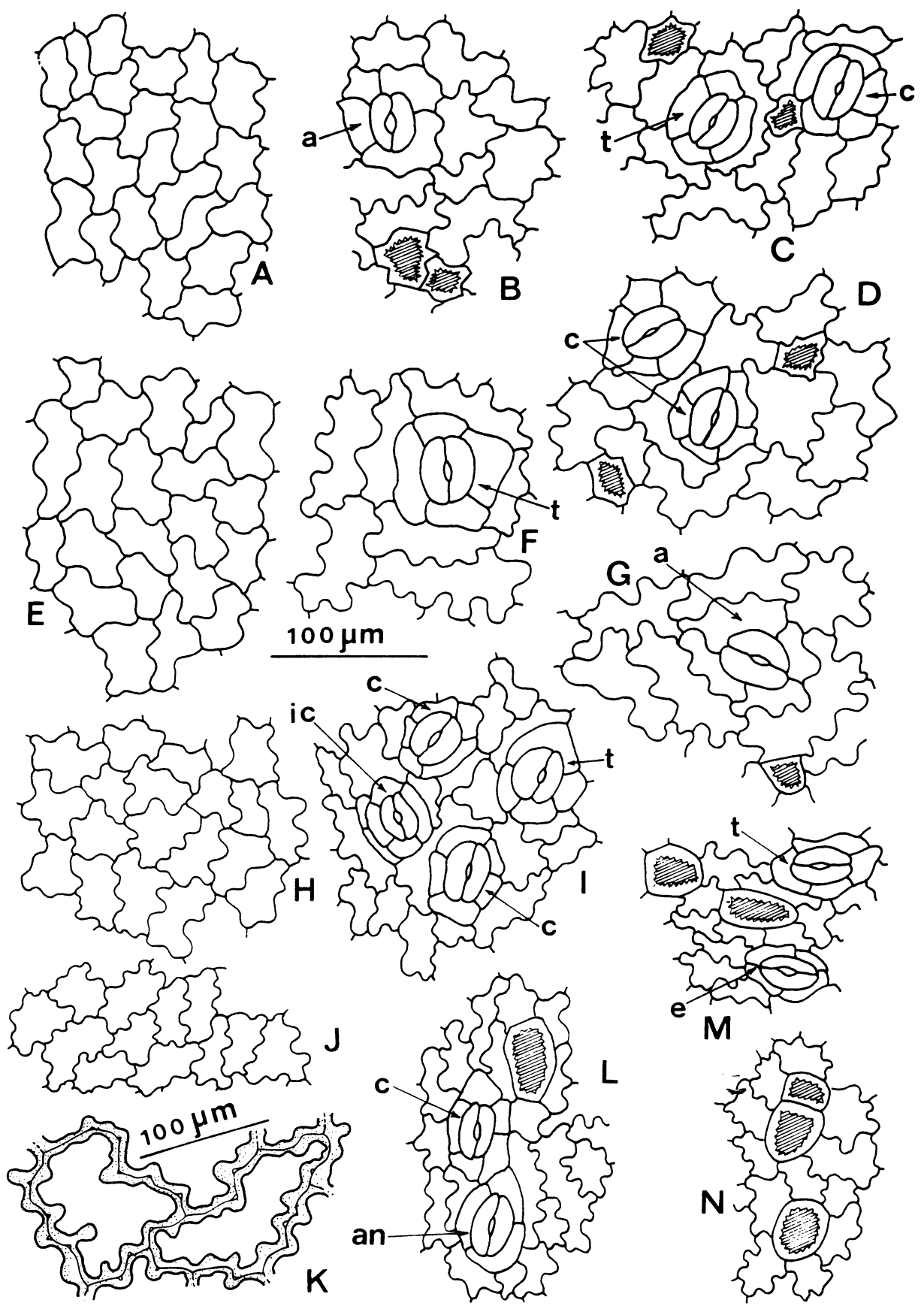

FIG. 4. Epidermis in Marattia. A. M. pellucida epiphyll. B-D. M. pellucida hypophyll. E. M. raddii epiphyll. F-G. M. raddii hypophyll. H. M. silvatica epiphyll. I. M. silvatica hypophyll. J-K. M. werneri epiphyll. L-N. M. werneri hypophyll. The stomata types are: a = anomocytic, an = anisocytic, $\mathrm{c}=$ cyclocytic, ic $=$ irregularly cyclocytic, and $\mathrm{t}=$ tetracytic. 
five different kinds: unbranched hairs, two-armed hairs, variously branched hairs, scales, and glandular hairs. Scales, non-glandular hairs, and glandular hairs intergrade in this material and probably share a common ontogenetic ancestor because in their earliest ontogenetic stages scales resemble glandular hairs, although they lack the tanniferous contents of the latter.

The distribution and nature of the indument varies in the species studied. Angiopteris and Marattia lack glandular hairs, but have non-glandular hairs and scales. In the former genus the hairs and scales occur along the costa and secondary veins in A. angustifolia, A. cartilagidens, A. evecta, and A. lygodiifolia, but appear solely along the costa in A. pruinosa. In Marattia, glabrous pinnae occur in M. attenuata and M. excavata. Indument occurs on the costae, secondary veins, and lamina surface of $M$. pellucida (Figs. 6S, T) and also on the lamina margins of this species and $M$. raddii. It is restricted to the costae in $M$. douglassii and M. fraxinea. Costal and superficial, but not marginal indument was observed in M. silvatica. In Danaea pinnae, glandular hairs are found on and near the secondary veins, but not on the costae. Hairs and scales like those of the lamina and secondary veins are also found more or less frequently along the costae. Trichomes like glandular hairs occur on the costae, but tests for tannin in these structures were negative; apparently these glandular hair-like structures are juvenile stages of the costal hairs and scales found in mature Danaea fronds. This strengthens previous observations of $D$. nodosa by Rolleri et al. (1987).

The indument of some species of Danaea and Marattia was described in detail for the first time by Rolleri et al. (1987). The study of a larger number of species in the present paper revealed additional variation in pinna indument between and within species.

Angiopteris angustifolia.-Peltate scales with one or two more or less cylindrical basal cells and a pauci- to pluricellular, flattened body deeply incised into very irregular segments that usually terminate in a pluricellular, biseriate hair occur on the costa (Figs. 5C, E, F) and secondary veins (Figs. 5A, $\mathrm{D} ; 5 \mathrm{~B}$, a lateral view of a small, peltate scale). Acute or conic, unicellular marginal processes are common.

Angiopteris cartilagidens.-Variously branched peltate scales with a single, short or long, cylindrical basal cell (Fig. 5L) or two short, subconic basal cells (Figs. 5G, K) and a paucicellular or porrect, flattened body prolonged in different directions by uni- or pluriseriate branches that end in awl-like processes are present. The larger scales are found along the costae, the smaller ones along the secondary veins.

Angiopteris evecta.-Variously branched hairs with one or two short basal cells and a 3- or 4-armed body (approaching simpler variously branched types) with irregular, commonly uniseriate, usually 3-celled branches terminated in an obtuse, cylindrical cell are distributed on the costa (Fig. 5S) and secondary veins (Figs. 5N-R).

Angiopteris lygodiifolia.-Peltate scales that are simpler and smaller than those observed in other species of the genus, with a cylindrical basal cell and a flattened, branched, paucicellular body with uniseriate, hair-like, U-shaped or 

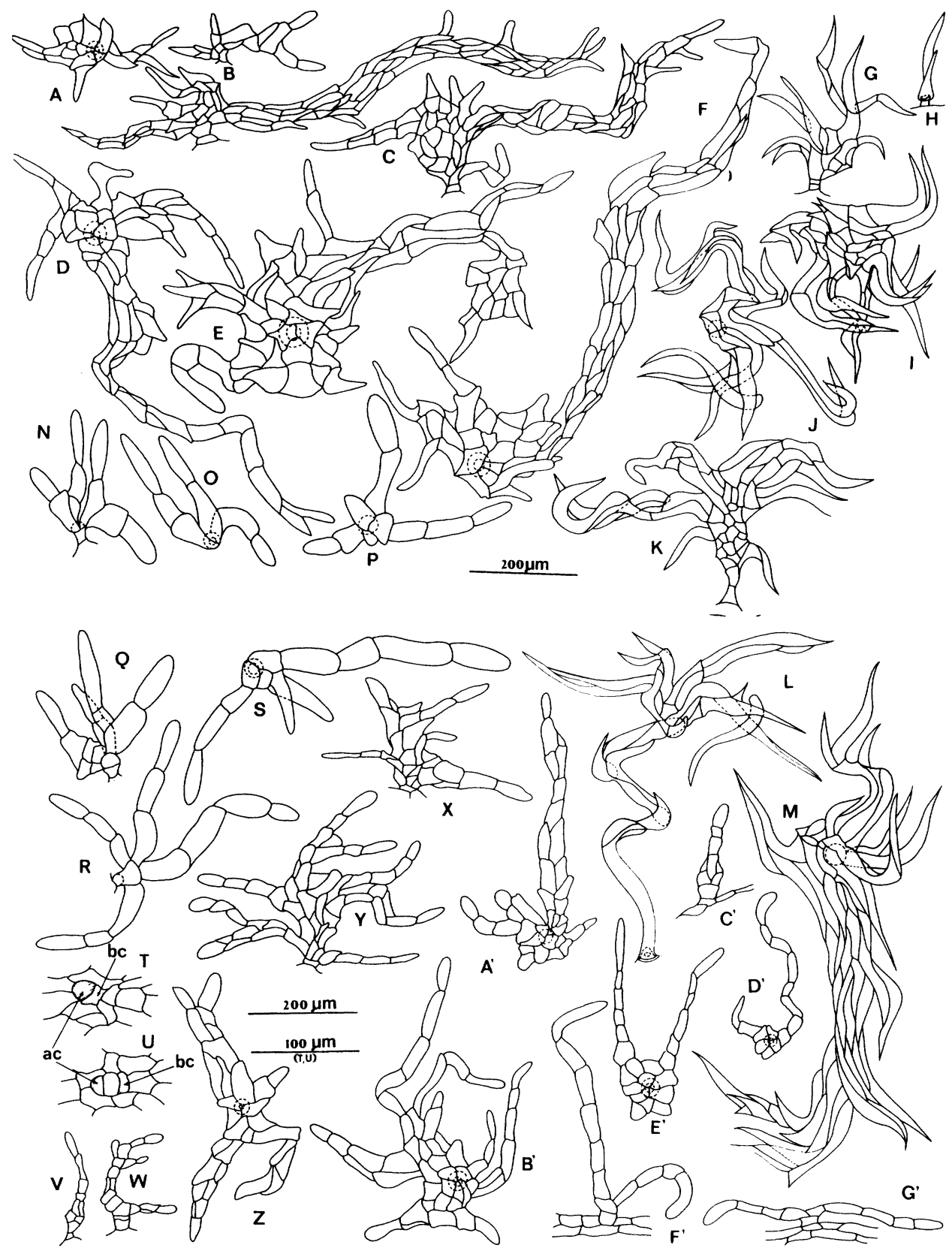

Fig. 5. Indument in Angiopteris. A, B, D. A. angustifolia scales on secondary veins. C, E, F. A. angustifolia scales along costae. G-M. A. cartilagidens scales on costae $(\mathrm{H}$ a common juvenile stage). N-R. A. evecta hairs on secondary veins. S. A. evecta hair on costa. T-W. A. pruinosa hair initiation along costae. $\mathrm{X}-\mathrm{Y}$. A. pruinosa dendritic hairs along the costae. $\mathrm{Z}, \mathrm{A}^{\prime}, \mathrm{B}^{\prime}$. A. pruinosa scales along costae. $C^{\prime}-E^{\prime}$. A. lygodiifolia scales on secondary veins. $\mathrm{F}^{\prime}-\mathrm{G}^{\prime}$. A. lygodiifolia hairs along costae. The cell types are: $\mathrm{ac}=$ apical cell, $\mathrm{bc}=$ basal cell, stippled $=$ cell arising from first division of the apical cell. 
irregularly tufted branches appear along secondary veins (Figs. 5D'- $\mathrm{E}^{\prime}$ ). Twoarmed hairs with one or two short basal cells and two horizontal, uniseriate arms that are T-shaped or variably V-shaped, each one ending in an obtuse cylindrical cell, are found on the costa (Fig. 5G'). Unbranched hairs with one or two short basal cells and a small, biseriate body with a uniseriate, hair-like apex are also found on the costa (Fig. $5 \mathrm{~F}^{\prime}$ ).

Angiopteris pruinosa.-Peltate scales with a cylindrical basal cell and a paucicellular, flattened body with 1- or 2-seriate branches radiating slightly from above the base, the branches ending in a 3- or 4-celled, uniseriate, hair-like process (Figs. 5Z, A', B'), are found along the costa. Pluricellular, variously branched hairs with a paucicellular, either massive or partially flattened body prolonged into uniseriate, hair-like processes (Figs. 5X-Y) are also found along the costa. These may be intermediate forms between scales and variously branched hairs. Unbranched or 2-armed hairs with one or two basal cells that closely resemble those seen in A. lygodiifolia (Figs. 5V-W) are also found along the costa. These may be juvenile forms of the foregoing variously branched hairs.

Marattia douglassii.-Peltate scales with a cylindrical or more or less obconic basal cell and a large, flattened, pluricellular body with deep incisions forming irregular, marginal, pluricellular or uniseriate hair-like structures, the former usually ending in acute cells, the latter in a cylindrical obtuse cell (Fig. $6 \mathrm{~A}$ ), were observed along the costa.

Marattia fraxinea.-Peltate scales resembling those of M. douglassii in shape, general features, and location occur (Fig. 6B).

Marattia pellucida.-Diverse indument types appear together in different locations on the same pinna: (1) Peltate scales resembling those of M. douglassii and M. fraxinea have been observed on the costa, lamina (Fig. 6R), and secondary veins. These are up to 5-6 $\mathrm{mm}$ long, the largest yet recorded in Marattia. (2) Peltate scales with one or two basal cells and a paucicellular, flattened, irregularly incised body bearing conic or acute cells or hair-like processes (Figs. 6U-W) occur on the lamina and near and upon the secondary veins mixed with hairs. (3) Unbranched hairs usually with a cylindrical basal cell and a 5- or 6-celled body terminating in a cylindrical, obtuse, 1-celled apex occur on the lamina and near and upon the secondary veins. (4) Unbranched, uniseriate hairs (Figs. 6S-T) and two-armed, V-shaped or T-shaped and horizontal hairs, the latter sometimes with unequal arms, the larger biseriate and longer (Figs. 6P-Q), were observed on pinna margins.

Marattia raddii.-Peltate scales resembling those of $M$. douglassii are found, large ones only along the costae, smaller ones (Fig. 6I) on secondary veins and the costa. Hairs with one or two short, basal cells and a massive, paucicellular body that is narrow and unbranched (Fig. $6 \mathrm{H}$ ) or branched and J-shaped, with each arm ending in a more or less cylindrical, obtuse cell (Figs. 6F-G, Y), occur on the lamina and near and on secondary veins.

Marattia silvatica.-Large, peltate scales closely resembling those of $M$. douglassii (Fig. 6K) occur on the costae. Two types of hairs occur on the lamina surface: (1) Branched hairs with one or two short basal cells and four or five 
uniseriate, occasionally branched arms directed in different directions (Fig. 6J, L); and (2) Hairs with one short basal cell (Fig. 6H) and unbranched or two armed, the latter V-shaped or more or less Y-shaped (Figs. 6N-O). The latter may be juvenile forms of the former.

Danaea species.-Glandular hairs and peltate scales occur on various parts of the laminae. Glandular hairs have a single basal cell that is hourglass-shaped and firmly inserted between two epidermal cells (Fig. 7K, a surface view). The body may be globose, paucicellular, and capitate (Figs. 7A-D, O-Y), more or less irregular (Figs. 7E, F, H, I, B'), or stellate (Figs. 7Z, A'-D'). Intermediates between these extremes are known. Irregular to very irregular stellate hairs were observed that resemble scales, with short, usually 1-celled arms radiating outward in all directions from a massive, few-celled body (Figs. 7J, Z, A', C', D'). Tannins are abundant in glandular hairs. The terminal cells of the arms of stellate trichomes are cylindrical or claviform and show strong positive reactions to tannin tests, whereas the body cells have a slightly weaker reaction. In the smaller, globose hairs having a markedly glandular aspect, all cells test intensely positive for tannin. Glandular hairs can be lost during the clearing procedure, but the short, lignified base remains. Peltate scales have a single, hourglass-shaped basal cell like those of the glandular hairs and a pluricellular, flattened, more or less regular to irregularly incised body. Conic or claviform cells (Figs. 7G, M, N, E') or hair-like, uniseriate, short processes may occur on the margin.

Glandular hairs are present over the lamina and on the costa in D. alata (Figs. 7A-F) and D. excurrens (Figs. 7O-U) and over the lamina in D. elliptica (Figs. $7 \mathrm{H}-\mathrm{J}$ ) and D. grandifolia (Figs. $7 \mathrm{~V}-\mathrm{Z}$ ). The latter two show a graduated series from simple, capitate types to large, stellate ones similar to those observed in $D$. nodosa (Rolleri et al., 1987).

Peltate scales always seem to be restricted to the costa. The most regular stellate forms were seen in D. elliptica (Fig. 7L, a transsection) and $D$. grandifolia (Fig. 7E'). Less regular types were found in D. alata (Fig. 7G) and D. excurrens (Fig. 7M, N). These are not tanniferious; the body is clear, evenly reddish-brown, and its cell walls are medium thick.

\section{IDIOBLASTS}

Silica-containing idioblasts (id) containing amorphous silicon appear regularly in species we studied. They are constant in Angiopteris and Marattia (except M. silvatica), but are lacking in Danaea (Rolleri et al., 1987). The silica forms large, amorphous bodies completely filling the lumen of the idioblasts, which are found singly or in groups of two, three, or more.

Idioblasts appear isolated or in groups of two or three in A. cartilagidens (Fig. 1G), M. attenuata (Fig. 3C), M. douglassii (Fig. 3F), M. pellucida (Figs. 4B-D), and $M$. raddii (Fig. 4G). These cells reach a high density, whether isolated or in groups of 3 to 9 , and are particularly noticeable in A. angustifolia (Fig. 1E), A. evecta (Fig. 1K), A. pruinosa (Fig. 1B), M. excavata (Figs. 3H, I), and M. werneri 

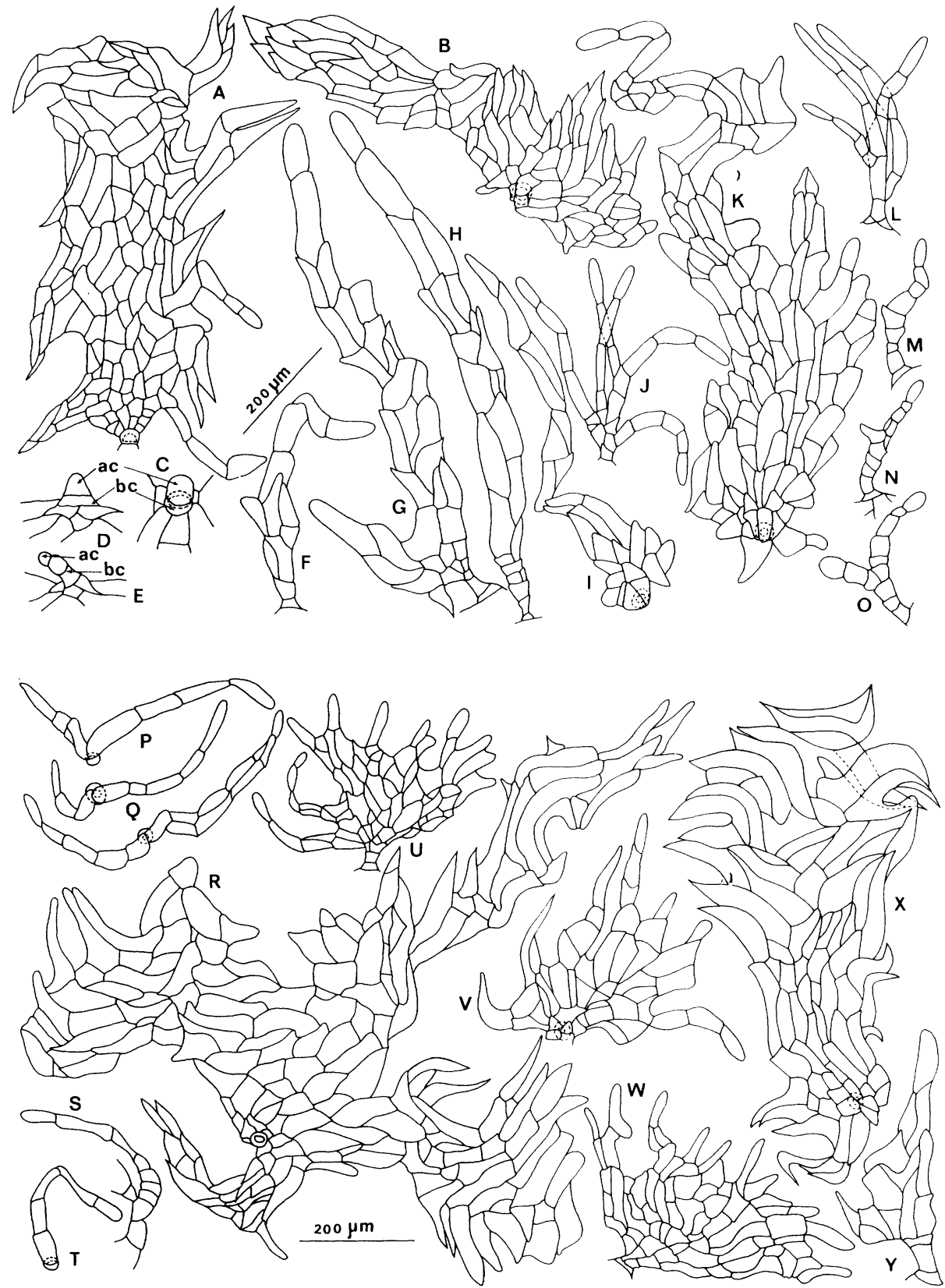

FIG. 6. Indument in Marattia. A. M. douglassii scales along costa. B. M. fraxinea scale along costa. C-E. M. fraxinea hair initiation along costa. F-I. M. raddii scales on secondary veins. J, L. M. silvatica branched hairs on lamina. K. M. silvatica scale along costa. M-O. M. silvatica hairs on laminae, perhaps juvenile forms. P-Q. M. pellucida hairs on laminae. R. M. pellucida large scale on costa. S-T. M. pellucida marginal hairs on laminae. U-W. M. pellucida scales on secondary veins. X. M. raddii scale on costa. Y. M. raddii hair on lamina. The cell types are: ac = apical cell, $\mathrm{bc}=$ basal cell. 
(Figs. 4L-N). In the last species, the idioblasts can be two to three times larger than the normal stomata (see Table 1).

Idioblasts have a markedly polygonal outline, which can occasionally be subelliptic, with the sole exception of M. pellucida (Figs. 4B-D), where they are irregular and have a sinuate outline.

\section{Discussion}

The following conclusions come from our present research as well as our previous studies on the epidermal morphology of the Marattiales (Rolleri et al., 1987, p. 145).

1) Characters shared by Angiopteris, Danaea, and Marattia include the presence of some epidermal hairs and scales only on the hypophyll, glabrous pinnae rare, sinuate epidermal patterns frequent, and adult cyclocytic stomata of different types found in roughly equal proportions (see Adult Stomata).

2) Characters shared by Angiopteris and Marattia but absent in Danaea include epidermal patterns polygonal and non-thickened, usually branched pinna hairs and scales diverse, glandular hairs absent, and idioblasts present (rarely absent in Marattia).

3) Characters shared by Danaea and Marattia but absent in Angiopteris include epidermal patterns distant-sinuate, epidermal cells thick-walled, and stomata terrestrial.

4) Characters exclusive to Angiopteris include epidermal cells thin-walled, stomata aquatic, and stomata very dense.

5) Characters exclusive to Danaea include epidermal patterns predominantly frequent-sinuate, epiphyll cells often very regularly isodiametric, wall thickenings of epidermal cells uneven, glandular hairs present on the laminae, secondary veins, and near the costae, non-glandular hairs and scales restricted to the costae, and idioblasts absent.

6) Characters exclusive to Marattia include epidermal patterns polygonal and forming very regular mosaics with uniformly thickened cell walls up to 4.5-5 $\mu \mathrm{m}$ thick.

Kondo \& Toda (1962), Thurston (1969), and van Cotthem (1973) studied the ontogeny and morphology of Marattialean stomata. In general, their results suggest that these structures had a perigenous development. According to his own observations and those of other authors, van Cotthem (1973) proposed a "separation of Christensenia and Danaea from the Marattiaceae sensu stricto consisting of Angiopteris, Macroglossum, Archangiopteris and Marattia. There are grounds for considering Christenseniaceae and Danaeaceae as separate families. There is no support for a separation of Angiopteridaceae and Marattiaceae."

Pant \& Khare (1969) found mesoperigenous ontogenies for Angiopteris evecta, and Rolleri et al. (1987) did so for M. alata and M. laevis (as M. kaulfussii). Furthermore, van Cotthem's (1973) subdivision, based as it was on stomatic types, should be rejected as shown by this and other papers (Rolleri et al., 1987). The great variation of adult stomata types and their coexistence in the 

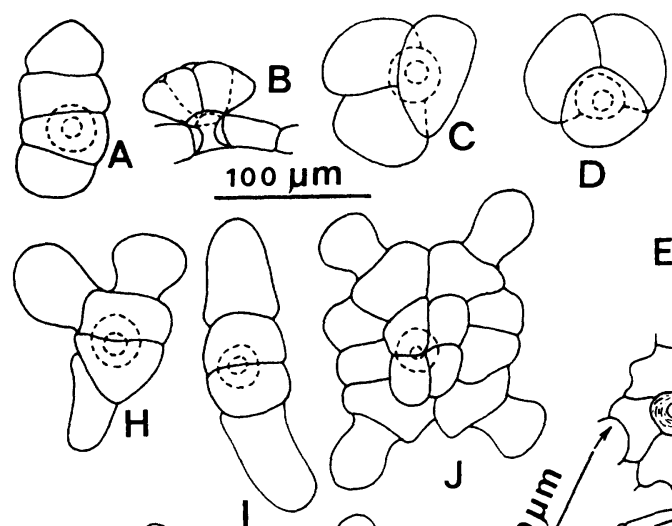

D

M

r
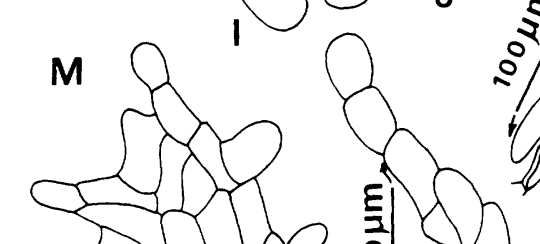

\section{$\mathrm{E}$}
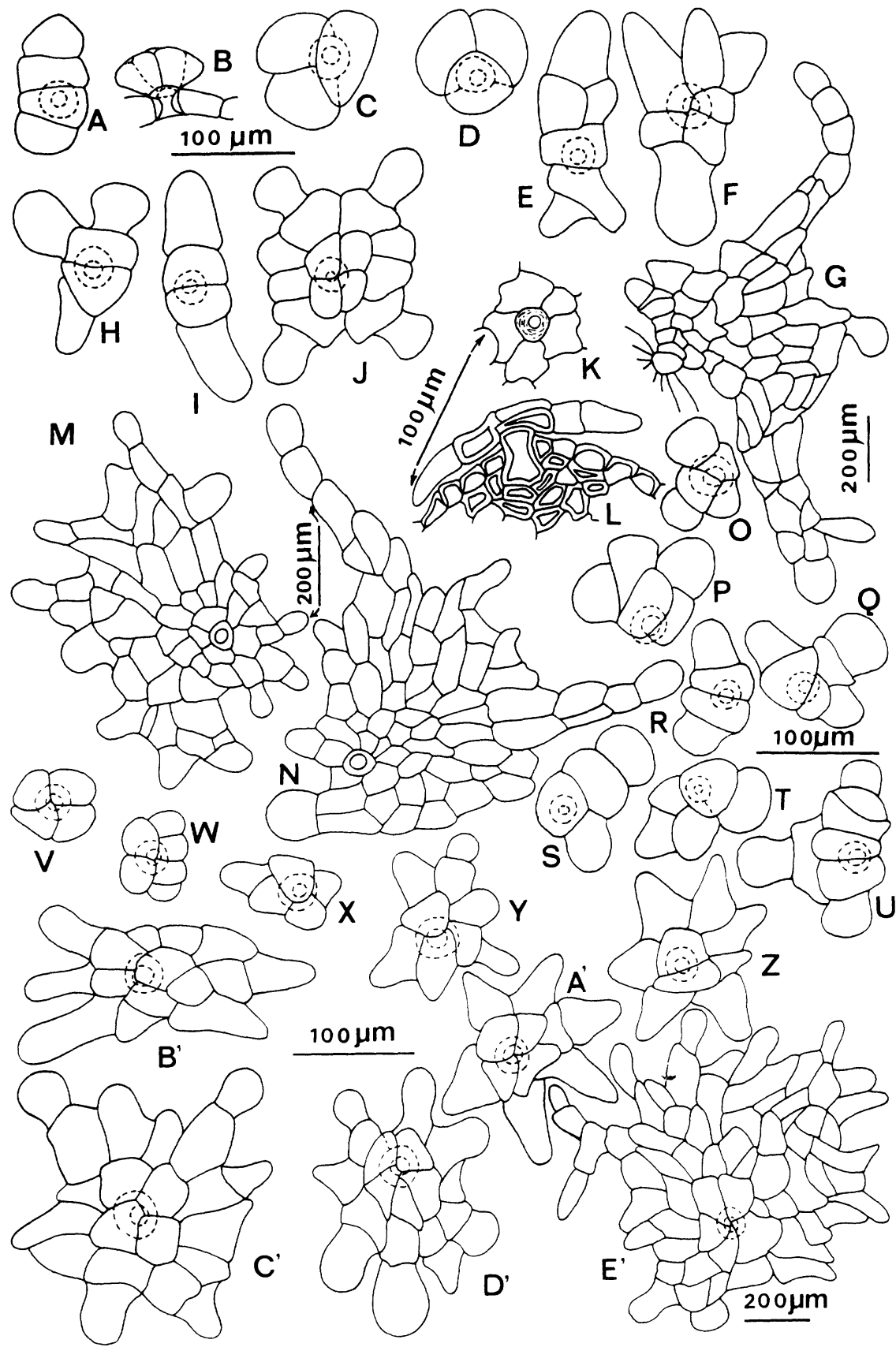

$\mathbf{R}$
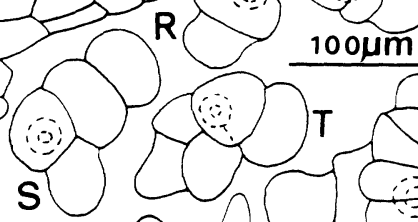

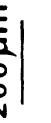

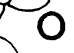

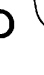<smiles>C1CC2CCC(C1)C2</smiles>
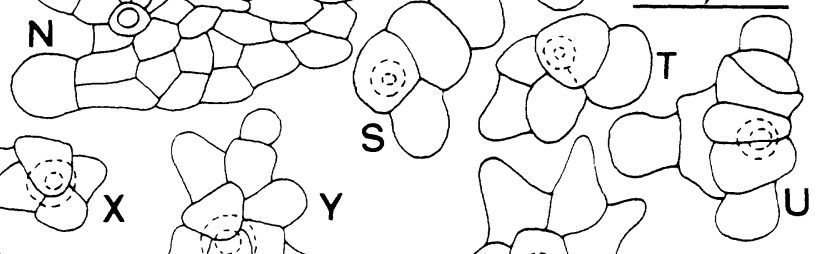

'

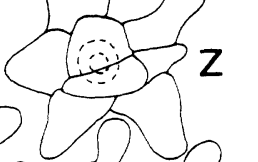

$100 \mu \mathrm{mm}$

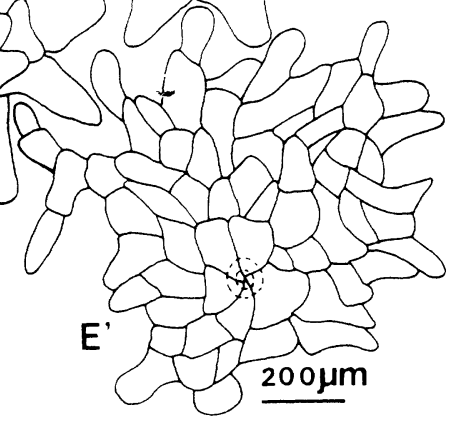

FIG. 7. Indument in Danaea. A-F. D. alata glandular hair on secondary veins and near costa. G. D. alata scale along costa. H-J. D. elliptica glandular hairs on laminae. K. D. elliptica surface view of base of hair. L. D. elliptica small scale with hourglass-like base in transsection. M-N. D. excurrens scales along costae. O-U. D. excurrens glandular hairs on laminae and near costae. $V-Z, A^{\prime}-D^{\prime} . D$. grandifolia glandular hairs on laminae. $\mathrm{E}^{\prime}$. D. grandifolia scale along costa. 
pinnae leave no ground for using that character to segregate Marattialean genera into families.

Epidermal patterns substantiate the general ideas that Angiopteris and Marattia are closely allied and that Danaea does not differ conclusively. It is remarkable, on the other hand, how alike the patterns of Danaea and, according to our current research, Christensenia are.

Indument must be taken into account for its diagnostic importance. Danaea and, according to our current research, Christensenia exhibit glandular and eglandular types. The former has never been found in either Angiopteris or Marattia, but general observations of the eglandular indument strongly suggest the affinity of all four genera.

Concerning the probable diagnostic value of epidermal characters, we suggest that:

1) Epidermal patterns point to affinities between Angiopteris, Danaea, and Marattia, rather than sufficient variations to segregate any of these genera into separate families. These patterns, combined with their epidermal characters, have diagnostic value at the species level (Rolleri et al., 1987, p. 145).

2) Morphology of the mature stomata is of no diagnostic importance, save for the fact that the genera studied here all have cyclocytic adult stomata. It remains to be seen whether variations in cyclocytic types will be useful in discerning genera or species of the Marattiaceae sensu lato.

3) Indument morphology suggests that Angiopteris and Marattia form a group separate from Danaea.

\section{ACKNOWLEDGMENTS}

This research was carried out through a grant from the Consejo Nacional de Investigaciones Científicas y Técnicas (CONICET) of Argentina. Thanks are due David Lellinger for numerous suggestions. Bernardo Dougherty (Museo de La Plata) made the first English draft of the manuscript. Virginia Dubarbier (CONICET) made the drawings.

\section{LiteRATURE Cited}

Cotthem, W. van. 1971. A classification of stomatal types. J. Linn. Soc., Bot. 63:235-246.

- 1971. Vergleichende morphologische studien über stomata und eine neue Klassification ihrer Typen. Ber. Deutsch Bot. Ges. 84:141-168.

1973. Stomatal types and systematics. Pp. 59-71, in A. C. Jermy, J. A. Crabbe and B. A. Thomas, eds. The Phylogeny and Classification of the Ferns. J. Linn. Soc., Bot. 67, Suppl. 1. Academic Press, London.

Foster, A. 1934. The use of tannic acid and iron chloride for staining cell walls in meristematic tissues. Stain Technol. 9:91-92.

FROHNE, D. 1985. Anatomisch-mikrochemüsche Drogenanalyse: ein Leitfaden, 3. überarbeitete und einvertete Auflage. Thieme, Stuttgart.

GuRR, E. 1965. The Rational Use of Dyes in Biology. Williams \& Wilkins, London.

HaberLandt, G. 1965. Physiological Plant Anatomy. Today and Tomorrow's Book Agency, New Delhi.

HILl, C. R. and J. M. CAMUs. 1986. Evolutionary cladistics of marattialean ferns. Bull. Brit. Mus. (Nat. Hist.), Bot. 14:219-300.

Holtrum, R. E. 1978. The morphology and taxonomy of Angiopteris (Marattiaceae), with a description of a new species. Kew Bull. 32:587-594. 
Johansen, D. A. 1940. Plant Microtechnique. McGraw-Hill, New York.

LeLLINGER, D. B. 1985. A Field Manual of the Ferns and Fern-Allies of the United States and Canada. Smithsonian Institution Press, Washington, DC.

Maroti, I. 1960. Histologische Untersuchungender Marattiaceae-Blätter mit besonderer Hinblick auf die Epidermis. Acta Biol. (Szeged) 6:71-89, t. 1-7.

MetCalfe, C. R. 1961. General introduction with special reference to recent work in monocotyledons. Pp. 146-150 in IXth Int'l. Bot. Congress, Recent Advances in Botany, vol. I. University Press, Toronto.

PANT, D. D. 1965. On the ontogeny of stomata and other homologous structures. Pl. Sci. 1:1-24.

PRoBst, W. 1971. Vergleichende Morphologie und Entwicklungsgeschichte der Sfaltöffnungen bei Farnen. Dissertation, Universität Stuttgart.

Rolleri, C. and A. Deferrari. 1986. Modelos epidérmicos y otros caracteres foliares en la sistemática y ecología de especies de Lycopodium L. sección Crassistachys Herter. Revista Mus. La Plata, n.s., Bot. 14:63-79, t. I-IV.

—, A. Deferrari and M. Ciciarelli. 1987. Epidermis y estomatogénesis en Marattiaceae (Marattiales-Eusporangiopsida). Revista Mus. La Plata, n.s., Bot. 14:124-147.

Stace, C. A. 1965. Cuticular studies as an aid to plant taxonomy. Bull. Brit. Mus. (Nat. Hist.), Bot. 4:1-78.

Stromberg, A. 1956. On the question of classification of stomatal types in leaves of dicotyledonous plants. Tbilisi Sci. Stud. Chem. Pharm. Inst. 8:56-67. (In Russian.)

TheOBald, W., J. L. KRAHUliK and R. Rollins. 1979. Trichome description and classification. Pp. 42-53 in C. R. Metcale \& L. Chalk, Anatomy of the Dicotyledons, 2nd ed., vol. I. Oxford University Press, London.

WiLKinson, H. P. 1979. The plant surface (mainly leaf). Pp. 97-165 in C. R. Metcalfe \& L. Chalk, Anatomy of the Dicotyledons, 2nd ed., vol. I. Oxford University Press, London. 